\title{
Novas Tecnologias Reprodutivas: Natureza e Cultura em Redefinição
}

Naara Luna As novas tecnologias reprodutivas, procedimentos da medicina de reprodução humana

FEBF/UERJ que substituem o ato sexual para a concepção, são objeto privilegiado na Antropologia para se debater a relação entre Natureza e Cultura. Importa discutir os fundamentos desse debate: as noções de cultura e de natureza também são construções sociais oriundas da cultura ocidental moderna (Strathern 1992). Segundo Laqueur (1992), o lluminismo marca o início de uma mudança epistêmica: o mundo físico passou a ser percebido como real e os significados culturais como epifenômenos. $\mathrm{O}$ corpo veio a ser então compreendido como o fundamento epistêmico para prescrições sobre a ordem social (op. cit.:6-7). Schneider (1968:23) lança a hipótese de que, sendo a conexão biogenética a definição fundante da concepção nativa norteamericana (EUA) de parentesco, a descoberta pela ciência de novos fatos sobre a relação biogenética pode acarretar a transformação das noções nativas ocidentais. A reprodução era exemplo de processo natural, porém a assistência prestada por novas tecnologias como a inseminação artificial e a fertilização in vitro tem posto em questão não somente a naturalidade do processo, como também a própria noção de natureza enquanto condições de vida das quais a intervenção está ausente (Strathern 1992:57). O recurso às tecnologias de procriação amplia as margens de escolha na reprodução e na constituição do parentesco, o que se contrapõe à representação deste como processo natural.

Este artigo ${ }^{1}$ examina o discurso de profissionais e pacientes envolvidos com a reprodução assistida e tratamentos convencionais de infertilidade com base em dados obtidos em observação etnográfica e entrevistas. Pacientes e profissionais foram contatados em diferentes serviços de reprodução humana ou por rede informal. 0 
dos informantes sobre vivências e práticas concernentes às tecnologias reprodutivas se fundamentam em diferentes articulações das categorias de Natureza e Cultura. Piscitelli, em artigo que resenha a produção feminista quanto à relação entre os conceitos de natureza, gênero e parentesco, identifica ali a obsessão por desnaturalização, isto é, em "compreender como os processos de construção de identidades e de laços sociais aparecem ancorados na natureza, na biologia ou em alguma instância divina" (1998:320). Este artigo aborda como as representações dos laços de parentesco e da concepção de pessoa são construídas no embate entre dois domínios, a Natureza e a Cultura, domínios estes que servem de fundamento para os critérios de atribuição de parentesco e pessoa.

O material incluído neste artigo contempla parte do trabalho de campo realizado durante o doutorado em Antropologia no PPGAS do Museu Nacional, UFRJ. ${ }^{2}$ Fez-se o exame de notas de observação etnográfica e de entrevistas gravadas ou com registro manuscrito. $\mathrm{O}$ artigo inclui quatro entrevistas gravadas em 2001 com mulheres que passaram por tratamento de reprodução assistida (inseminação artificial e fertilização in vitro). Essas informantes foram contatadas através de rede de amizades. Eram mulheres de classe média com nível superior de instrução que fizeram o tratamento em clínicas privadas ${ }^{3}$. O texto leva em conta também duas entrevistas gravadas com médicos ginecologistas que realizavam apenas inseminação intra-uterina, um dos quais trabalhava no serviço público e o outro, em clínica particular. Nas entrevistas com mulheres que passaram por reprodução assistida, priorizou-se o enfoque na experiência pessoal com as técnicas durante o tratamento e em questões éticas. Aspectos técnicos e éticos constituíram os tópicos principais das entrevistas com profissionais da área.

Outra parte do material procede de observação etnográfica no ano de 2002, que abrangeu pacientes e profissionais de instituições que oferecem tratamento convencional para esterilidade (Instituto de Ginecologia da UFRJ) e também reprodução assistida. Entre as últimas, visitei o Setor Integrado de Reprodução Humana da UNIFESP (antiga Escola Paulista de Medicina), a Divisão de Reprodução Humana do Hospital Pérola Byington (um hospital estadual centro de referência para a saúde da mulher) e o Centro de Reprodução Humana e Fertilização Assistida do Hospital São Lucas (privado), todos na cidade de São Paulo. No caso do Instituto de Ginecologia da UFRJ, no Rio de Janeiro, a pesquisa consistiu em observação de consultas no Ambulatório de Reprodução Humana com registro dos dados solicitados pelos médicos sobre o histórico da infertilidade e tratamentos. Durante as consultas, sempre que houve oportunidade, indagou-se às pacientes a respeito da vivência da esterilidade, bem como quanto à família e à adoção. Após as consultas, foram realizadas algumas entrevistas com registro apenas manuscrito (sem gravação), em que se perguntou sobre reprodução assistida. $O$ artigo contempla entrevistas com cerca de 30 pacientes, em sua maioria apresentando quadro clínico compatível com encaminhamento para reprodução assistida (gravidez tubária, laqueadura e obstrução tubárias). As pacientes dos serviços públicos pertenciam às classes populares em sua maioria, com um pequeno número de usuárias das camadas inferiores da classe média. 
Esse material heterogêneo está sob exame neste artigo. Analiso as representações de pessoa e parentesco expressas no discurso de pacientes e profissionais a partir de núcleos temáticos estruturantes comuns. Schneider constata a oposição entre ordem da lei e ordem da natureza na simbólica de parentesco dos EUA (1968). Enquanto a ordem da Natureza é o fundamento inexorável da realidade em geral (Laqueur 1992), o que abrange o parentesco, a ordem da lei corresponde à Cultura, dimensão socialmente construída, portanto revogável e transitória. Tratase da oposição entre o que é construído como dado (a Natureza) e o que é dado como construído (a Cultura) segundo a definição de Roy Wagner (1981). Oriento meus questionamentos verificando se esta oposição ocorre com respeito às noções de pessoa e de parentesco nos discursos analisados. Investigo se há um patamar comum de significações de parentesco que atravesse divisões de classe e de posição (paciente ou profissional).

Neste artigo, abordam-se primeiramente os núcleos temáticos que estruturam o discurso dos informantes com respeito ao parentesco: a oposição entre sangue e adoção, o amor como categoria central na simbólica de parentesco ocidental, o sangue como idioma de pertencimento, o amor resultante da criação, a gravidez como processo da criação e finalmente a circulação das substâncias germinativas (sêmen, óvulos, embriões). No tocante à concepção de pessoa, examinam-se os processos de personificação de entes biológicos e o debate sobre o estatuto do embrião humano extracorporal. Consideram-se, por fim, outros tópicos recorrentes na observação e nas entrevistas: a discussão sobre a intervenção tecnológica na reprodução natural e a fundamentação da natureza na dimensão transcendente, esta perceptível nas referências à divindade. A articulação de Natureza e Cultura perpassa todos os núcleos temáticos, com a evocação de parâmetros ora sociais ora biológicos para definir as relações de parentesco (Costa 2003), o que se estende também para a representação de pessoa.

\section{O SANGUE E O FILHO DOS OUTROS}

Fonseca (2002) observa que a ênfase na escolha e afeição caracteriza a concepção de família moderna. Por outro lado, ocorreu nas duas últimas décadas a revalorização das concepções biológicas de parentesco, perceptível na busca da reprodução assistida como meio de engendrar filhos, bem como na identificação de parentesco, especialmente de paternidade, por meio dos testes de DNA (2002:273). Há um ar de modernidade tanto no acesso às técnicas como nas posturas individualistas das novas famílias, com seu acento na escolha. Tenho como pressuposto que esse aspecto moderno na aparência fundamenta-se em concepções tradicionais como o parentesco de sangue. Esse ponto se explicita no discurso dos informantes, que opõe o filho do sangue e o adotado. 
A adoção é mencionada às vezes espontaneamente por várias das entrevistadas e aparece mesmo como sugestão dos médicos. O questionamento sobre a adoção faz aflorar a reflexão dos informantes sobre reprodução e parentesco. A reação mais comum ao tópico é a de Madalena: "Vontade de ter o filho meu mesmo"; "Só vou pensar em adoção se os médicos disserem que eu não posso mais engravidar". O tratamento para engravidar coloca-se como prioridade. Tal é o caso de Rogéria, que repete as preocupações do marido: "Ele acha que se eu pegasse a criança, eu iria parar ou relaxar com o tratamento por causa do bebê. Ele quer ter o filho dele, e esse é filho dos outros". Uma minoria descarta totalmente a adoção. Rogéria diz que sentiu "discriminação" (sic) por parte da sogra quando falou em adotar: "Colocar filho dos outros em casa!" Essa reação negativa não parte apenas dos parentes afins, mas também da mulher que se trata, conforme as palavras de Mariana:

“Um monte de gente disse: 'Ah, por que você não adota?' Eu falei: Não. Não quero. Não tem nada a ver comigo. Nem com ele. (...) Eu queria ter o meu filho, da minha barriga, engravidar. (...) Uma coisa assim: da minha carne, sangue do meu sangue".

O parentesco revela-se nas próprias palavras das pacientes como um idioma de pertencimento: o meu filho mesmo é oposto ao filho dos outros. Deseja-se uma comunhão de substância com os filhos, por isso se fala em "minha carne", "meu sangue". O sangue é a imagem central. Em pesquisa com homens em tratamento de infertilidade, Costa (2003) encontrou o mesmo contraste entre o filho de sangue e o filho dos outros. Embora os laços de sangue possam ser interpretados em termos de conexão biogenética (Schneider 1968), referindo-se às características físicas da pessoa, as informantes que manifestaram receio quanto à adoção mencionaram com maior freqüência traços de temperamento e sociais. Rosilda fala: "Se fosse adotar, ia querer recém-nascido. Grande, com 3 ou 4 anos, não quero, porque já vem rebelde". Mariana continua: "Porque vai que a criança tem um problema, você vai falar assim: pô, não é meu filho. Veio do sangue... Sei lá de quem que é esse sangue? Puxou a quem? Essa má índole".

Há o receio das origens desconhecidas: uma paciente do Hospital Pérola Byington diz que "não sabe tratar filho dos outros, depois pode virar traficante, marginal. (...) Não sabe se é da geração, se o pai era traficante". Clarice recebeu conselhos de jamais adotar de uma conhecida sua, mãe adotiva, pois ela havia pegado "não um bebê recém-nascido, mas uma serpente recém-nascida que herdou tudo de ruim dos pais. A filha se droga que nem a mãe que era drogada e por isso deu o bebê". Várias dizem ter sabido pelo rádio ou pela televisão de filhos adotivos que matam os pais, mas nem sempre se atribui ao sangue o problema: Karina conta que sua tia adotou uma menina que depois engravidou de um rapaz drogado. Embora a tia afirme que isso ocorreu porque a filha veio de outro sangue, Karina acredita que isso vem da educação. 
Também houve a preocupação de que a criança herdasse doenças. Quando ofereceram um bebê para Rogéria adotar, ela teve medo, porque na família havia pessoas "paralíticas, a avó era cega, a mãe não era boa da cabeça" - todos "parentes de sangue da mãe do bebê". Esse temor às vezes surge no casamento. Clarice tem medo de ter filhos com o mesmo problema das irmãs do marido, que manifestaram doença mental após os 18 anos. O médico do serviço privado disse considerar um grande desgaste adotar uma criança:

“Você vai criar um filho dos outros na sua casa: uma pessoa de um lugar diferente que pode vir com uma doença de fora, que pode vir com doenças genéticas, que pode vir com doenças congênitas. (...) Você está pegando uma criança que você não sabe como é geneticamente, se vem com defeito".

É interessante como, nas palavras desse médico, o desconhecido e o externo estão associados. Definese um não-parente na qualidade de uma pessoa que vem de fora e sobre a qual não há informações. Teme-se o desconhecido como fonte do mal, seja este em caráter, seja em comportamento, seja em enfermidade. Segundo Costa (1988), o filho adotivo estaria excluído do "sangue compartilhado", que é o princípio de pertencimento à família, e traz um "sangue desconhecido". Faltam ao adotivo as conexões naturais com a família de adoção, o passado compartilhado em laços genealógicos comuns e o conhecimento dos "parentes verdadeiros". Quando há informações de que os parentes de sangue têm doenças, como no caso do bebê oferecido à Rogéria ou dos parentes afins de Clarice, teme-se também a herança do que é conhecido. A preocupação com a herança genética de doenças fomenta a medicalização do parentesco e da família (Finkler 2001), perceptível nas questões de Clarice, Rogéria e do médico. Considerando todos os depoimentos acima, pode-se afirmar que o sangue transmite atributos sociais e naturais. Segundo Abreu Filho (1982), o sangue é uma substância que transmite características físicas e morais, formando o corpo e o caráter. Nesse caso, o indivíduo é explicado por referência a seus consangüíneos. Como resultado dessa transmissão de atributos, a pessoa já nasce moralmente constituída, representante de uma família, de uma tradição. Assim o sangue articula a ordem da Natureza e a ordem da Cultura.

\section{CRIAR AMOR}

Segundo Schneider (1968), no parentesco norteamericano o amor é um símbolo central que une o aspecto do parentesco como comunhão de substância biogenética (ordem natural) e o parentesco como código de conduta (ordem da lei socialmente estabelecida). O amor é o guia para os relacionamentos em família. Há duas variedades: 
o amor conjugal, que é erótico; e o amor cognático, que une as pessoas de mesmo sangue. $\mathrm{O}$ amor se opõe ao dinheiro, que é material, impessoal e desprovido de considerações de sentimento e moralidade. Uma mulher grávida ofereceu a Alice seu bebê, desde que ela pagasse suas compras e aluguel. Embora ela e o marido quisessem o bebê, eles acharam errado dar dinheiro: "a mãe vender a criança". O casal manifestou resistência a misturar dinheiro e amor, opondo-se a relações de mercado influírem sobre as de parentesco. Alice é uma das mulheres em tratamento de esterilidade que apresentam posição ambivalente. Por um lado, ela pretende fazer tudo o que estiver ao alcance para engravidar, recorrendo à adoção só em caso de insucesso total; por outro lado, não resistiria se oferecerem em suas mãos um bebê. Ela diz: "O amor é o mesmo. Pai é quem cria”. Na sala de espera do Hospital Pérola Byington, ouvi uma paciente suspirando: “Ah, se me oferecessem um bebezinho... Mãe é quem cria e dá amor". Lurdes fala sobre filhos adotivos: "A diferença é que não saiu de dentro da gente, mas a gente pega amor rápido". Várias discordam. Marcela, baseada em sua própria experiência de ter sido criada pela mãe e pelo padrasto, sem jamais poder conhecer o pai, afirma: "Amor por filho adotado não é realmente amor de pai, amor de mãe". Rita não sabe se teria amor por filho adotado. Marilu justifica:

“Nunca quis adotar. (...) Eu acho que eu não amaria um filho adotado, porque (...) eu amo o meu filho de paixão, mas um filho dá muito trabalho. Eu não me arrependo porque é meu filho. Se eu tivesse adotado, às vezes eu poderia me arrepender: para que é que eu fui pegar esse menino dos outros? (...) Vou devolver".

A observação de Marilu aponta para o contraste entre o parentesco biogenético e o parentesco como código de conduta. Este último seria revogável, daí o pensamento de devolver o filho. É a inexorabilidade do laço biogenético como origem da pessoa que faz Marcela sempre ter pensado no pai desconhecido. $\mathrm{O}$ laço de sangue percebido como natural teria a qualidade de algo que não pode ser desfeito, ao contrário dos laços socialmente estabelecidos que dependem da escolha pessoal (Schneider 1968). Essa dimensão de escolha é um dos pontos que causariam desconforto com o processo de adoção para Mariana:

"Até eu adotaria sim, se batesse na minha porta. Eu adotaria uma criança se tivesse uma coisa assim: o filho de uma pessoa muito próxima que não tem capacidade, que não pôde. Agora, uma coisa assim, eu pegar e escolher... porque eu acho que rola sempre aquela coisa: a pessoa vai querer aquele lourinho bonitinho, não sei quê. Ninguém vai querer adotar um pretinho, doente, não sei quê.

No depoimento de Mariana está a crítica ao acento eugênico que a escolha de filhos adotivos poderia implicar, em contraste com a 'naturalidade' dos laços de sangue. 


\section{SANGUE COMO IDIOMA DE PERTENCIMENTO}

O sangue, conforme visto acima, abrange características físicas e sociais dos parentes. Os laços de sangue são símbolos de pertencimento entre pessoas, no caso, das relações de filiação. Marilu coloca sobre a semelhança com o filho: "É legal para caramba você ver umas coisinhas dele que são suas. Não é só físico não, também o teu jeito". Quando perguntei a Carolina se pensaria em recorrer à fertilização in vitro para engravidar, ela reagiu com a questão: "Bebê de proveta sai com a cara do pai?" A continuidade entre pais e filhos é esperada nessa manifestação de semelhança física. Alice diz que a diferença entre adotar e ter é "ver a barriga crescer, ver se o bebê tem a cara do pai, a cara da mãe". A falta de semelhança pode gerar suspeita. Rogéria conta de um caso em família em que o filho saíra a cara de um ex-namorado de sua parente e não do atual companheiro que registrou a criança. $\mathrm{Na}$ segunda gravidez da mulher, o companheiro ameaçou "fazer o DNA" do primeiro filho e do outro que ela estava esperando. Ele disse que "não queria levar gato por lebre". Fonseca $(2002,2003)$ constatou que a possibilidade de fazer exames de DNA como prova de paternidade tem incitado muitos homens em dúvida sobre a paternidade biológica de seus filhos a buscar a investigação. Vê-se o teste de DNA como prova inconteste de parentesco ${ }^{4}$. Quando explicava para Alice sobre o processo de clonagem por transferência nuclear utilizado para gerar o personagem Léo na novela O Clone, observei que, embora o óvulo de Deusa fosse enucleado previamente, havia DNA residual fora do núcleo ${ }^{5}$. Ela então perguntou: "Se fizer o teste de DNA acusa? Se acusar, a mãe é a Deusa".

As preocupações quanto ao recurso à reprodução assistida relacionam-se à formação do parentesco. Perguntei a Carla se ela aceitaria a doação de óvulos para engravidar e ela devolveu a questão: "De quem vai ser o sangue?" Dirigindo a mesma pergunta a Priscila, ela indagou: "O filho vai deixar de ser meu?". Marilu não aceitaria receber a doação de óvulos, porque isso impediria a comunhão de substância entre ela e o filho: “Não é da minha barriga, é do meu óvulo. (...) Eu quero ter o filho ali que é meu, que tenha uma parte de mim, tem meu sangue, tem meu eu ali, tem meus DNAs ${ }^{6 "}$. A associação de carga genética com sangue nem sempre coincidiu. Carolina teve reação semelhante quanto à doação de óvulos: "Vai ser meu filho? Do meu sangue?" Expliquei que o óvulo contendo o DNA seria de outra. Quando perguntei em seguida se aceitaria ser mãe por intermédio de uma barriga de aluguel (mãe gestacional substituta), ela foi firme: “Não, porque não ia ser do meu sangue, eu ia estar só emprestando o meu óvulo e o do meu marido" (sic).

Quando a reprodução assistida exige material germinativo que envolve outras pessoas além do casal, algumas condicionaram a aceitação da técnica à participação de parentes. Eneida aceitaria doação de óvulos "só se fosse das irmãs, de outra não. (...) É porque está tudo em família". Uma profissional conta que uma postulante a receber óvulos insistia para usar os gametas da irmã, da filha, da mãe. A profissional tentou convencer a postulante da 
necessidade do anonimato da doadora, o que permitiria à receptora manter segredo sobre a doação, se desejasse, pois em conflitos familiares uma irmã doadora poderia revelar à criança ser esta filha dela (irmã da mãe) com o pai. As posturas antagônicas de Eneida e da profissional levantam as questões principais a respeito da doação de óvulos entre irmãs. A primeira vê favoravelmente porque há proximidade entre irmãs tanto por compartilharem a mesma substância como pela colaboração pressuposta entre elas. Já a segunda posição vê na doação uma ameaça aos relacionamentos existentes (Edwards 1999:73ss). Quando perguntei a Rosemary sobre a possibilidade de solicitar a outra mulher que fosse a mãe substituta na gestação da criança, ela colocou: "Só se fosse minha irmã. Na minha irmã, eu confio". A expectativa é de que uma parenta tão próxima não se recuse a entregar a criança ao casal. Rogéria recorreria às suas tias para gerarem o filho dela na barriga, porém duvida que elas fossem lhe entregar o bebê, pois adoram criança. O vínculo de amor surgido durante a gestação é evocado pelos informantes de Costa para rejeitarem o recurso a uma barriga de aluguel (2003). Rosemary e Rogéria, sem saber, estavam consoante as regras do Conselho Federal de Medicina que permite a "doação temporária de útero" apenas entre parentes próximas da mãe genética e sem caráter comercial. Há uma convergência entre a Resolução 1358/92 do CFM e as posturas de Rosemary e Rogéria, que pressupõem a colaboração desprendida entre mulheres parentes próximas, conforme constatado por Edwards acima.

\section{MÃE É QUEM CRIA: A ORDEM DA LEI}

Algumas informantes haviam passado pela experiência de 'criar' o filho do companheiro ou de pessoas pertencentes ou não à família. Andressa chegou a disputar na Justiça a guarda da filha da irmã que ela criava como sua. Eneida $\mathrm{e}$ o marido criaram por um tempo os filhos de uma mulher que havia se separado do marido. A mulher, porém, quis as crianças de volta: "Ela chegou, levou e não deu nem obrigado". Perguntei se não haviam pensado em entrar na Justiça e ela respondeu: "não, mãe é mãe", uma resposta que confirma a constatação de Fonseca (1995) sobre a idealização dos laços consangüíneos entre mãe e filhos nas camadas populares. Penélope criava a filha do marido, mas a mãe da menina a quis de volta. Penélope resolveu então "ter um filho meu mesmo, que ninguém possa tomar de mim". A revogabilidade do arranjo é um dos temores que envolvem essas transações com crianças. A expectativa de Penélope de que ninguém poderia tomar um filho "dela mesmo" funda-se no caráter perene imputado aos laços 'naturais' de substância biogenética, conforme a análise de Schneider (1968).

A ambigüidade desses laços 'naturais' quando as tecnologias de procriação envolvem o recurso à doação de óvulos ou ao empréstimo temporário de útero faz surgir o receio de que a relação possa ser desfeita. Quando 
perguntei se aceitariam que seu óvulo fecundado com o espermatozóide do seu marido fosse para o útero de outra mulher (a barriga de aluguel) que depois iria entregar a criança ao casal, várias responderam como Rita: "Não. É muito complicado. Acontece igual à novela e a mulher não quer dar o filho"7 . A reação de Jane é semelhante quando pergunto se aceitaria a doação de óvulos: "Não, porque a mulher ia dizer que o filho era dela e ia ser uma batalha sem fim". Depois que expliquei que a doadora não iria conhecê-la, Jane disse que aceitaria. Outras informantes também a princípio recusaram receber doação de óvulos, mas mudaram de idéia quando informadas de que a doação era anônima.

As soluções para o impasse são semelhantes às apresentadas para a adoção. Andressa, com base em sua experiência, diz: "para pegar para criar, a criança tem que ser bebê e a mãe verdadeira se afastar". Costa já assinalou essa necessidade de evitar relações com a mãe ou a família de origem na adoção à brasileira realizada com o auxílio de uma mediadora (1988). Da mesma forma, na etnografia de Ragoné (1994) sobre arranjos comerciais de maternidade substituta nos EUA, considera-se desejável após o nascimento a mulher que deu à luz a criança evitar o casal. Em uma palestra de apresentação dos métodos de reprodução assistida, o médico palestrante destacou a garantia do anonimato da doadora entre as dificuldades de um programa de doação de óvulos, pois em uma clínica pequena é difícil impedir que esta e a receptora se encontrem ${ }^{8}$. Acima já se viu o exemplo de dissuasão da paciente que queria escolher doadoras em sua família. Salem (1995) sustenta que a exigência de anonimato ou segredo sobre a mãe biológica ou sobre os doadores de gametas está relacionada à percepção de que os laços socialmente estabelecidos são intrinsecamente frágeis em contraste com os 'naturais'.

Em certas circunstâncias, dá-se ênfase aos laços sociais. A médica, após explicar a uma paciente sobre seu quadro de esterilidade, aconselha-a a adotar: "ser mãe não é ter barriga, é criar e dar amor". A prioridade dos laços revela-se quando a mesma médica comunica a outra paciente da pequena chance de uma cirurgia de reversão de laqueadura tubária dar certo: “Ser mãe não é ter barriga. Ser mãe é cuidar da criança. Seu marido é o pai dos seus filhos. Claro que não é pai genético, biológico, mas é pai". A última observação, frisada em itálico, indica que a parentalidade social seria uma variedade mais fraca da relação.

$O$ aspecto social é relevante quando se pensa em legalizar a relação de filiação. Amanda comenta que uma mulher grávida the ofereceu o bebê. Amanda não aceitou porque "queria uma coisa legalizada e não de boca. (...) Não quero ninguém depois na minha porta fazendo confusão". O caráter social de contrato, mesmo sem ser estabelecido juridicamente, é evocado nas relações de gestação substituta (barriga de aluguel). Renata destaca que existe "parceria" (sic) entre a gestante e a fornecedora do óvulo. Comentando sobre a novela Barriga de Alugue/, Renata defende que o filho era daquela que "pagou e fez o contrato. $O$ direito era dela. (...) A barriga de aluguel deveria dar a criança porque houve o acordo". O caráter racional e deliberado do acordo para a maternidade 
gestacional substituta é posto em destaque por Karina em contraste com o acontecido com a personagem Deusa, da novela $O$ Clone, que teria sido enganada: "A barriga de aluguel faz um acordo. Deusa fez um investimento, um procedimento para o filho ser dela".

\section{GRAVIDEZ É CRIAR}

Os laços entre mãe e filho não se estabelecem apenas por dotação genética. Algumas priorizam o vínculo obtido durante a gestação, considerada um tipo de maternidade mais verdadeiro do que a maternidade genética por doação de óvulos. Jane, referindo-se à novela Barriga de Aluguel, diz que a mãe era a que gestou:

“A mãe é a que botou para fora. (...) Eu torcia por Clara. Estava na barriga dela. Ela é que sentiu as dores e viu a barriga crescendo. Cada enjôo, cada dorzinha, cada colicazinha. Mas a outra não sentiu nada! Só por causa do óvulo dela?"

A dor do parto pode ser um momento de definição da maternidade. Quando perguntei a llze se tanto fazia engravidar ou adotar, ela respondeu: "É melhor você ter para sentir a dor. Aí você é mãe depois de sentir o gostinho". Catarina afirma: "Adotar não é a mesma coisa (...). A mulher tem que sentir a dor. Pegar o filho criado não é a mesma coisa" ${ }^{\prime 9}$. A gravidez é um processo de criação do qual a mãe participa ativamente. Betânia diz que queria tentar o bebê de proveta "para ver o corpo se modificar durante a gravidez. É diferente de pegar o bebê já pronto. (...) la ver o corpo 'delatar' (sic), também os peitos. (...) Aceitaria doação de óvulos porque ninguém ia saber que não era meu. Eu é que ia ter e amamentar".

A recepção das novas tecnologias reprodutivas pode implicar um novo olhar sobre processos como a gravidez, antes descrita principalmente como um fato natural. Luísa, quando diz que concordaria em receber a doação de óvulos, justifica: "É a mesma coisa que pegar para criar, com a vantagem de nascer da própria barriga". O processo de gestação é equiparado aqui ao tratamento dado pela mãe adotiva que cuida de uma criança sem ter laços genéticos com ela. Cussins (1998) assinala que em algumas instâncias a gestação está sendo assimilada ao cuidado que se tem pela criança após o nascimento. O natural é socializado em uma cadeia de transações de significados entre o natural e o cultural. O caráter social da gravidez é destacado por Diana em sua rejeição irônica à doação de óvulos: "Minha barriga iria crescer, mas não teria nada de meu. Seria o mesmo que adotar, mas teria a satisfação de ver a própria barriga crescer. Uma satisfação para mostrar à sociedade que pode engravidar". 
troca de substâncias que vai da alimentação aos sentimentos. Betânia fala da gravidez da personagem Clara em Barriga de Aluguel: "Ela merece mais porque ela deu amor. Ela se tratava para ele ser sadio. Tudo o que ela comia ia para ele". Marilu, que teve seu filho por fertilização in vitro, fala da transmissão de temperamento durante a gestação:

“Qualquer coisinha eu explodia ou eu chorava muito. (...) Durante minha gravidez morreu uma amiga, amicíssima minha, num acidente de carro. (...) O mundo se acabou para mim, acho que é por isso que meu filho chora hoje. Ele chora por qualquer coisinha, as lágrimas jorram no rosto. Ele chora com dor. Acho que eu passei isso para ele durante a gravidez".

Em sua entrevista, o médico do serviço privado também fala da importância da alimentação da gestante para a constituição do bebê como um modo de comunhão de substância entre a mãe gestacional e o feto:

“Se nascer um filho saudável, aquela mãe é que deu vida a ela. Então aquela mãe tem participação no crescimento daquela criança. Tranqüilamente. Ela não é geneticamente. Mas tem sangue dela. Tem proteína dela que entrou ali dentro. Ela comeu a proteína que se transformou nela e deu (...) para aquela criança".

Esse exemplo demonstra que o compartilhar de substância entre parentes não se reduz à conexão genética. Analisando a comensalidade como modo de constituir relações de parentesco entre os malaios, Carsten (1995) assinala que o comer junto começa no útero antes do nascimento.

\section{A CIRCULAÇÃO DE SUBSTÂNCIAS GERMINATIVAS}

O contato permitido pelas tecnologias de procriação entre substâncias germinativas e órgãos da reprodução em laboratório ou consultório médico, mesmo se dando fora da relação sexual, suscita a preocupação ou o simples gracejo. Elizete gostaria de ter filhos novamente de outro jeito, através da reversão de laqueadura em vez da fertilização in vitro, pois já viu casos na televisão em que "usam outro óvulo ou espermatozóide, e o bebê nasce sem o DNA da pessoa". Mariana brinca com a possibilidade de troca de material no laboratório:

“Se viesse um japonês, o erro não era meu. Não tinha problema. A única vez que não tem problema... Se vier um lourinho, um japonês, a culpa não é minha. A culpa é do médico que errou. (...) Trocou o embrião lá. A culpa não é minha. Eu não traí o meu marido". 
Mariana brincou que se houvesse troca do material germinativo ela não poderia ser acusada de infidelidade, mesmo que o filho nascesse diferente dos pais. Algumas informantes opuseram-se à doação de gametas como sendo ocasião de adultério. Andressa mostrou-se contrária à doação de esperma: “Não, porque é pecado e também porque o esperma não ia ser do marido, então não ia adiantar. Isso seria adultério e fornicação". Quando objetei que não há adultério sem relação sexual, Andressa foi taxativa: "Não ia ter, mas ia ter o esperma de outro homem dentro de mim". Priscila rejeitou a doação de esperma e o recurso a uma mãe substituta para a gestação na mesma base:

“Daria problemas no relacionamento, tanto com o esperma do marido na barriga de outra mulher, como com o esperma de outro na barriga dela. Na hora da briga, um poderia jogar na cara do outro. Prefiro o equilíbrio: nenhum dos dois ter e adotar".

Costa (2003:72) ouviu afirmações semelhantes de homens em tratamento ambulatorial de infertilidade ou orientação para planejamento familiar, constatando que não se concebe o fluido corporal dissociado do percurso da transmissão. Rita fez o seguinte comentário sobre a possibilidade de receber doação de óvulos: "É do meu marido e não é meu. É de outra pessoa. Olha a traição incubada". Essa traição "incubada" ou virtual, porque não realizada com o ato sexual, foi a preocupação de Andressa e Rita. O contato com a semente de alguém externo ao casamento pode gerar o desequilíbrio na relação, conforme o comentário de Priscila. Ela prefere que o casal se iguale através da adoção, em que nenhum dos dois procria. A recusa da doação de sêmen e a preferência pela adoção como solução igualitária foi a orientação predominante entre os entrevistados de Costa (2003). Gilda coloca uma condição para aceitar a doação de óvulos: "Desde que o marido nunca tivesse tido nada com ela" (a doadora). A postura de Gilda, valorizando a inexistência do ato sexual em si como condição para aceitar a doação de óvulos, diverge da posição de Andressa, Priscila e Rita.

Todavia a representação de infidelidade pode escapar do senso comum. Marilu, que teve seu filho por meio da fertilização in vitro, aceitaria que o marido tivesse filhos com outra mulher, pois assim o filho de Marilu teria irmãos.

$M$ - Se ele fizesse um filho com alguém e trouxesse para morar e eu criar, eu criaria, apesar de ser contra a adoção. Mas aí é o filho do meu marido, o irmão do meu filho.

$\mathrm{N}$ - Aí ele pode ter bebê de proveta com outra pessoa.

M - Se ele fizesse bebê de proveta com outra pessoa? Ah, não sei. Aí não. Aí já é demais também, né? 
Nesse exemplo a infidelidade maior seria fazer a reprodução assistida com outra mulher em lugar de manter relações sexuais com ela, invertendo o senso comum sobre adultério. Talvez esteja em jogo aqui a solidez do relacionamento do casal: enquanto o adultério pode ser uma relação casual, a reprodução assistida implicaria um projeto do casal de conceber o filho (Tamanini 2003). A exceção seria a maternidade substituta, quando uma mulher de fora do casal engravida deliberadamente para atender às necessidades deste.

As relações de parentesco podem se confundir com a aplicação das tecnologias de procriação. Gilda brincou com a irmã de seu marido que ela poderia servir de substituta na gestação para o casal, mas reconsiderou: "Acho que não pode, porque você é irmã dele e vai gerar o filho do seu irmão, seu sobrinho". A insinuação de relações incestuosas tornaria a prática reprovável. Segundo Strathern (1999), a conotação incestuosa surge mesmo sem o ato sexual porque os parentes, no caso irmão e irmã, cada qual como indivíduo já integra a mesma rede de relações. No exemplo, a tia da criança nascida poderia ser vista também como sua mãe. A proibição do incesto relaciona-se à circulação de fluidos entre os corpos, pondo em contato substâncias idênticas (Héritier 1994:11). Irmão e irmã partilham da mesma substância que seria posta em contato por ocasião da gestação substituta. Cussins cita um caso semelhante em que a irmã serviu de substituta gestacional para o irmão e sua esposa. Os envolvidos concluíram que só haveria relações incestuosas se houvesse contato entre os gametas dos irmãos. 0 fato de não chamarem de incestuosa essa relação de engendramento de filhos seria um exemplo de que certos estágios na concepção e nascimento de uma criança podem ser considerados relevantes e entrar na configuração do parentesco, ou ser considerados irrelevantes e ignorados (Cussins 1998). A interpretação do laço genético como relevante para o parentesco em detrimento da gravidez fez com que uma irmã gestar o filho de seu irmão não fosse qualificado de relevante e incestuoso. Considerando relevantes para o parentesco os vários estágios para concepção e nascimento, Priscila apresentou uma visão pluriparental em seu comentário sobre a novela Barriga de Aluguel: "Ambas se sentiam mãe, uma por ter gerado, outra por ter doado o óvulo e o esperma do marido".

Na doação de gametas, a compatibilização das características físicas do doador com as do receptor é norma prevista pela Resolução 1358/92 do CFM, além de uma preocupação entre os que manipulam gametas e possíveis receptores. A margem de escolha dos doadores anônimos se restringe aos que apresentam "semelhança fenotípica e imunológica". Gilda aceitaria doação de óvulos de uma pessoa parecida fisicamente com ela, para que o filho não ficasse diferente dos pais. Uma profissional de um serviço de reprodução humana encarregada de organizar o projeto de um banco de sêmen perguntou-me se como antropóloga eu poderia dar algumas dicas sobre a caracterização do fenótipo dos doadores. Sua dificuldade era classificar os nordestinos. Ângela candidatou-se a doadora de óvulos em uma clínica particular ${ }^{10}$. Respondeu a uma bateria de questões sobre sua saúde e ouviu da profissional encarregada da seleção que sua aparência era excelente (morena clara com cabelos castanhos lisos 
e olhos castanhos). A profissional desinteressou-se da doação quando descobriu que a mãe de Ângela era negra. Contei esse fato a uma profissional de outro serviço de reprodução humana, que achou perfeitamente justificável a exclusão da candidata, pois as pessoas querem ter filhos parecidos com elas, mesmo recorrendo à doação de gametas ${ }^{11}$. Essa prática de compatibilizar características físicas dos doadores e dos receptores é designada por Salem (1995) como manipulação social das origens genéticas, em que se tenta mimetizar o parentesco biológico. A legitimidade das relações de parentesco engendradas pelas tecnologias reprodutivas pressupõe a proximidade com as relações de parentesco de origem genética. A falta de semelhança entre a criança concebida por meio de doação de gametas e os seus pais pode revelar o segredo da doação, com o risco de a filiação ser considerada ilegítima.

A qualidade das substâncias germinativas pode ser interpretada como índice de atributos não só físicos, mas morais, de seus fornecedores. A médica de um serviço de infertilidade explicava à paciente sobre a necessidade de o marido fazer um espermograma: "O exame é para ver se o espermatozoidezinho que está no líquido dele consegue chegar até o seu útero. Não é para ver se ele é homem ou se é brocha. É só para medir espermatozóides." A explicação deixa claro de que modo valores de gênero relacionados à masculinidade, tais como virilidade e potência, são sugeridos na compreensão do exame. Costa também sublinha a associação feita entre esterilidade e impotência por seus informantes (2003).

Os papéis de gênero podem não se curvar às evidências médicas. Cleide conta que o marido não deu atenção ao resultado baixo do exame, pois acha que mulher tem mais obrigação que homem na hora de ter filhos. Um estudante de medicina atribuiu à anatomia o fato de somente a mulher procurar o médico para saber se ela não pode ter filhos: "No homem, os órgãos são externos, aí ele vê que produz esperma e pensa que é fértil". A paternidade é valorizada como parte do papel masculino, conforme se vê no exemplo de Rita sobre seu marido: “Ele diz que não é um homem completo porque não é pai".

O papel masculino na reprodução pode ser mais ameaçado pela doação de esperma do que o papel feminino com a doação de óvulo. Nesse sentido, Priscila comenta que é mais fácil a mulher aceitar a doação de óvulos que o homem a de sêmen. Karina acha que, na doação de esperma "o homem ia ficar cismado de que o filho não é dele. Na doação de óvulos a mulher não fica cismada, porque a gravidez é dela"12. Ao associar a gestação com a maternidade e a contribuição da semente com a paternidade, Karina está reproduzindo uma antiga visão de parentesco que persistiu no Ocidente até o século XVIII (Finkler 2001). Nessa concepção monogenética de parentesco, a maternidade significa dar nutrição e dar à luz e a paternidade é o poder gerador (Strathern 1995). Na doação de óvulos, o papel tradicional materno na gestação está garantido, enquanto o papel masculino na paternidade é substituído pelo doador. A doação de gametas é um exemplo de que juridicamente nem sempre o vínculo genético 
é equivalente à paternidade: se o marido consentir que sua esposa faça tratamento de reprodução assistida com uso de sêmen de doador, valerá o critério da aliança oriundo do direito romano para designar a paternidade, isto é, pai é o companheiro da mãe (Costa 2003). É questionável se o critério no caso é a aliança entre marido e mulher (de parentesco) ou a escolha (do indivíduo) consciente de aceitar uma procriação no casamento com o auxílio de terceiros para doadores. Em ambos os casos haveria o predomínio da Cultura (escolha ou aliança) sobre a Natureza (vínculo genético).

A simbólica de gênero associada à masculinidade reflete-se no comentário ouvido por um homem quando sua mulher ia se submeter a uma inseminação intra-útero. $O$ profissional o advertiu sobre a pequena probabilidade de êxito, porque seu último espermograma feito imediatamente antes do procedimento apresentou alterações: "É como ir para a guerra sem armas". Eis uma imagem de gênero masculino associando fertilidade e belicosidade.

As substâncias germinativas do casal podem ser vistas como uma só, em vez de duas separadas. Ângela contou ao marido sobre sua intenção de doar óvulos. O marido discordou e disse que não "ia distribuir os filhos dele por aí". Ela não conseguiu convencê-lo que a contribuição com os gametas dela não implicaria a transmissão de traços hereditários do marido.

\section{AS NOVAS PESSOAS}

Chamar a doação de gametas de distribuir filhos é um exemplo de personificação ${ }^{13}$. Marilu repete o comentário que ouviu dos médicos enquanto monitoravam sua ovulação por meio de ultra-sonografia: "Seus ovários não têm trinta e oito anos. Gente! Seus ovários são maravilhosos". Os ovários de Marilu assumem uma condição de pessoa que tem idade cronológica. A troca do material germinativo no laboratório associada ao adultério foi tema de brincadeiras do médico de Mariana, amigo do casal, por ocasião da coleta de sêmen para realizar a fertilização in vitro:

“Aí, meu marido fez a retirada do espermatozóide. Ele (o médico) pegou o espermatozóide e falou: 'deixa ver se está tudo bem'. Aí, ele foi lá: 'não, estão todos bem'. Até mexeu com ele: 'só tem um problema: eles são louros e cabeludos'. Meu marido é careca".

Mariana fala disso rindo. A brincadeira envolve a personificação dos espermatozóides caracterizados com uma aparência incompatível com a do homem do par reprodutivo, o que implicaria a troca de material, gerando 
prole ilegítima. Outro exemplo de personificação envolvendo o óvulo, além do espermatozóide, veio de uma profissional de serviço de infertilidade em sua descrição das diferenças entre os procedimentos da fertilização in vitro clássica e sua variante com micromanipulação, a ICSI (injeção intracitoplasmática de espermatozóide). Na primeira, se "colocam o espermatozóide e o óvulo para namorar". Emily Martin (1991) analisou, em livros usados nas faculdades de Medicina nos Estados Unidos, a personificação do óvulo e do espermatozóide como um romance de conto de fadas que reproduz os estereótipos de gênero. Quando falam com leigos, é comum profissionais da área de medicina reprodutiva usarem linguagem afetiva para facilitar a comunicação. Durante uma palestra, o médico de um centro de reprodução humana projetou a imagem da placa de Petri contendo um embrião formado por fertilização in vitro e continuou a explicar o processo de transferência dos embriões: “Tira-se o embrião do bercinho com pipeta...". Não somente a peça sobre a qual se colocam óvulo e esperma para fertilização in vitro é chamada de bercinho mas, no final da palestra, ele perguntou à embriologista se o laboratório estava ocupado. Ela disse: "Há bebês", referindo-se aos embriões.

O caso do embrião é especial, pois se trata do ser a quem se atribui com maior freqüência e em discursos distintos as características de pessoa. Em sua análise sobre as novas tecnologias reprodutivas, Strathern (1992) afirma que os embriões vivos extracorporais gerados por meio de fertilização in vitro são a nova figura de pessoa jurídica que emergiu com o advento dessa tecnologia de procriação. A doutrina da Igreja Católica sobre a procriação contribui para essa representação ao estabelecer que há um ser humano desde o momento de fertilização de óvulo e espermatozóide, independentemente do meio em que se encontrem, isto é, no corpo de uma mulher ou em um laboratório (cf. Luna 2002). Em sua entrevista, quando perguntado sobre a manutenção de embriões extracorporais congelados, o médico do serviço público colocou: “É caro e é um problema, porque o embrião é protegido por lei". Perguntei a ele também que estatuto deveria ser atribuído ao embrião.

“Você obedece à lei. Na verdade, em tese, qualquer matéria viva tem que ter alguma, principalmente o embrião, quer dizer; é um pré-homem. É um pré-humano. Afinal de contas, todos nós fomos aquilo. E está lá: se você manipular aquilo, teoricamente, você poderia ter sido manipulado antes. Se você mata aquilo, você mata, não um homem, mas uma... um pré-homem, um projeto de homem. Rigorosamente, você está cometendo um pré-homicídio ou um homicídio de um pré-indivíduo."

A condição de pessoa do embrião foi definida por esse médico em termos filosóficos como primórdio do ser humano, condição universal da existência de todos $^{14}$. Estive presente a uma reunião de uma equipe de embriologistas em que se discutiram os critérios técnicos de seleção e de exclusão de embriões para transferência e a linguagem se manteve técnica. Nem em termos filosóficos nem em termos afetivos foi evocado em qualquer momento o caráter 
de pessoa daquele ser, mas sim a sua viabilidade em função de aspectos da morfologia durante o desenvolvimento. Dependendo de a quem se dirige, o discurso dos profissionais da área de medicina reprodutiva pode oscilar entre a linguagem técnica, conceitual e abstrata da ciência e a linguagem afetiva do parentesco. Perguntei a uma profissional da área de reprodução assistida o que era um embrião. Ela disse que, fora da barriga da mãe, era pré-embrião e depois discorreu sobre o desenvolvimento embrionário. Ela não considerava problema o descarte dos embriões que não se desenvolvessem nos meios de cultura providenciados no laboratório. Nesse sentido, dizer que o ente é embrião apenas no útero materno é defini-lo de forma relacional, como também reconhecer que, se os técnicos de laboratório pararem os procedimentos para o cultivo, o embrião não se desenvolverá autonomamente. Mais tarde, conversando com outro membro da equipe sobre uma transferência embrionária a ser realizada, a mesma profissional falou em "colocar os nenês" e depois se corrigiu rápido. No discurso de pacientes e profissionais da área, a referência aos embriões constantemente os dota de atributos de pessoa. Quando Marilu telefonou para o laboratório da clínica após a aspiração dos óvulos para saber se houve a formação de embriões recebeu a seguinte resposta:

“'A gente está trocando fralda de três, mas tem mais para fecundar ainda'. Já tinha três fecundados. Eles ficam brincando assim: 'estou trocando fralda', porque para eles já são bebês. Aí eu fiquei super feliz: Ah, meu Deus! Graças a Deus são três! Já tem três prontinhos!"

A própria Marilu reconhece que os profissionais envolvidos falam dos embriões como se já fossem bebês. No momento da transferência, o médico de Marilu avisou:

“ 'Olha, nós temos quatro bebês. Vamos colocar os quatro, ou você tem medo de ficar grávida dos quatro?' Eu falei: 'Não. Pode colocar'. Então eu acredito que tenham sido só quatro, pelo que ele me falou assim, foram só quatro. E pronto. Acho que ficou só quem queria ficar. Quem Deus programou para vir mesmo".

Ao comentar sobre os embriões transferidos, Marilu já lhes atribui vontade própria para se decidirem a ficar e individualidade para serem incluídos no plano divino. Após a transferência, no momento exigido de repouso, ela aproveitou para assumir um papel materno diante dos embriões para que esses se implantassem: "Aí fiquei lá conversando com o bebê: não sai. Mamãe está ensinando você. Não sai". Perguntei a Marilu se ela doaria embriões caso os tivesse em grande número: "Doaria sim, mesmo sabendo que eu ia ter um filho na mão de alguém." A relação parental está clara. Uma vez nascidos, os embriões doados seriam filhos de Marilu criados por outras pessoas. Quanto à possibilidade de congelar os embriões, Marilu colocou: 
“Eu até congelaria, faria para ter outros filhos depois, mas eu acho que ia ficar meio grilada: será que isso vai ser uma pessoa legal? Se não vai ter nenhuma alteração, sabe? De personalidade. (...) Porque, quando você faz a proveta, são dois dias, três dias ali, vindo para o teu útero logo. Você tem o aconchego dele e tal. E congelado não. Três anos ali congelado? Aquele embriãozinho lá?"

Marilu preocupa-se que o procedimento de criopreservação vá alterar não as propriedades biológicas, mas a personalidade de quem vier a nascer. Contrasta o aconchego do útero materno, em que o embrião está com sua mãe, com o isolamento de um embrião congelado. Marilu admitiria também a possibilidade de doar seus embriões excedentes para pesquisa. Essa última opinião de Marilu parece condicionar o caráter do embrião como pessoa e filho à sua perspectiva de nascimento. O embrião em si para ela não é sagrado, ao contrário da postura de Edna, que comenta sobre a destruição de embriões congelados na Inglaterra:

“Eu não sei imaginar como nós vamos responder isso perante Deus. (...) Toda vida eu acho que tem um significado. Eu acho que Deus, Ele dá a vida... por algum motivo. Eu sou contra o aborto... também. (...) Aí eu acho que... gerar uma vida tem um significado. (...) Então eu até tenho umas dúvidas, como que nós humanos vamos responder perante o que a gente está fazendo aqui no mundo em relação a essa coisa da reprodução assistida, dos embriões congelados".

A postura quanto à sacralidade da vida do embrião pode restringir os procedimentos médicos que um profissional adota. Em sua entrevista, o médico do setor privado coloca sua posição:

Dr. - “Mas entrou, entra um monte de conceitos de congelamento de embrião, um monte de coisas que eu não concordei, que eu não concordo. Entendeu? Por questões religiosas, por questão doutrinária. (...) Ética não. A minha discordância é de conceito. Por exemplo, eu sou contra o congelamento de embrião. Porque, o que acontece: você colhe cinco embriões, coloca três. Ela engravida e não quer mais colocar os outros dois. E eles vão para onde?" $\mathrm{N}$ - "Para o tubo de nitrogênio."

Dr. - “E depois de cinco anos, joga fora. No nosso conceito de religião, aquilo ali é vida. No meu conceito religioso, no meu conceito doutrinário, aquilo ali é vida. Pode ser que para outro não seja. É um conceito meu e eu tenho que lutar a favor dos meus conceitos."

Introduzi o problema do embrião apenas aos profissionais e às entrevistadas que passaram por reprodução assistida. De todas as entrevistadas no Instituto de Ginecologia, apenas uma mencionou espontaneamente sua preocupação com o destino dos embriões. Dalila provém de família católica bastante religiosa e tem um parente padre com quem discutia essas questões. Ela é totalmente contrária ao aborto e não gostaria de recorrer à fertilização in vitro por questões religiosas, já que "muitos fetos (sic) morrem e outros são congelados. Fazem uns sete e põem todos, aí só sobram três e a mulher tem que abortar. Os outros são congelados". 
Débora foi a entrevistada que apresentou a maior preocupação ética com a manipulação dos embriões:

“[Eu] tinha uma preocupação de que se a gente fertilizasse um ou dois óvulos, que eles fossem transferidos. O embrião que tivesse conseguido fazer que ele fosse transferido na condição em que ele estivesse. (...) Porque eu acho assim: é embrião, já é ser vivo. (...) O embrião é vida. (...) Porque, quando você está nesse meio, tudo parece natural, tudo parece possível, nada é problema, tudo é certo. Você pode congelar. Você pode doar. Você pode desprezar. Você pode fazer o que você quiser. Sem essa questão ética. (...) Sempre foi uma preocupação constante da gente é que o nosso material não fosse reutilizado. Inclusive eu cheguei a perguntar para o médico, a conversar sobre isso. Porque para mim estavam lidando com vidas mesmo. Mesmo o embrião, o primeiro que eu fiz a transferência e não... e não houve a implantação, é um filho que você perdeu. Querendo ou não é um filho, porque ele teve algum tempo de vida. Teve uns dias de vida no laboratório. Teve não sei quantas horas de vida no organismo, mas teve. É um filho que você não teve".

Débora compreende o embrião como um ser vivo que merece respeito. Os embriões gerados pelo casal já eram filhos deles desde que estavam no laboratório. O embrião que não se desenvolveu é um filho perdido. A noção de individualidade desses seres desde a concepção está presente em um registro fotográfico que ela guardava: "Eu tenho a fotografia dos embriões: com seis células, oito células. Um pouquinho antes de transferir. Como que eles estavam. E você vê bem a diferença do desenvolvimento de um e de outro".

Embora esses embriões tivessem vida autônoma, a dimensão relacional do parentesco se estabelece desde a notícia de que houve a concepção. Débora parece viver uma gravidez mesmo fora de seu corpo, antes da transferência: "Quando você recebe a notícia de que eles fecundaram realmente, para mim, naquele momento, eu estava grávida". O cuidado de Débora era tão grande que contrariou os princípios de eficiência aplicados na medicina reprodutiva. Houve a aspiração de três óvulos, mas ela quis que apenas dois fossem fertilizados, a despeito dos conselhos de médicos e biólogos. Quanto ao óvulo não utilizado, ela fala: “Perdeu-se, né? É uma célula. Depois ele também não tem vida prolongada". Embora se preocupasse que seu material reprodutivo e o do marido não fossem reaproveitados para outra pessoa, ela não lamenta o destino do óvulo descartado, pois seu estatuto é diferente.

Mariana é a única que teve embriões em excesso para implantar de uma só vez: “Eu tenho sete embriõezinhos congelados". O casal tem o plano de transferi-los no futuro. A fala sobre eles é afetiva e nunca em termos filosóficos ou abstratos: "A gente vai tirar e vai descongelar o bichinho. (...) A gente até brinca quando passa em frente. Meu marido sempre fala 'yes, yes, yes' e manda beijinho para os filhos". Assim, o casal vê os embriões como filhos. Segundo as normas da clínica, explicitadas no protocolo de consentimento informado, se o casal deixar de existir, os embriões devem ser descartados: "Ele [o médico] faz um documento para a gente (...) que, se a gente se separar ou um dos dois morrer, ele elimina". Mariana não se opõe a essa idéia e diz que aceitaria que, em caso de sua morte, o marido transferisse os embriões para a nova mulher: “Eu até assinaria se eu morresse e ele quisesse utilizar. (...) 
Mas eu viva, eu não daria não, porque estaria dando o meu filho". Mostra-se completamente contrária a doar seus embriões e os personifica como filhos já nascidos: “Doar o embrião, para mim, é a mesma coisa que uma doação, que uma adoção... que uma doação de filho mesmo, que uma adoção". O sangue é a justificativa para se recusar a doá-los: "É pelo fato de você pensar: aquele filho é teu. É sangue do meu sangue". Quando perguntei o que era o embrião fora dela, Mariana o incluiu mesmo antes de seu desenvolvimento nas relações de filiação do casal: “Já é um filho meu. Apesar de estar lá, de não ter se desenvolvido, já é um filho meu. É meu e do meu marido. É de nós dois". Essa última opinião poderia dar a entender que Mariana identifica os embriões como merecendo o respeito devido ao ser humano em abstrato, conforme constatado nas opiniões do médico, de Edna e de Débora. No entanto, a posição de Mariana sobre a doação de embriões para pesquisa científica é reveladora:

“Eu não dou para outra pessoa, mas para pesquisa, eu doaria numa boa. (...) É coisa de cuca em relação a ser teu sangue. Entendeu? Ser meu sangue. Eu vou ficar: como é que será essa criança? (...) Eu tenho sangue e ele vai falar mais alto. Então, eu não encararia. Agora para pesquisa, sim. Acho que eu estaria ajudando para outras coisas. Eu estaria ajudando também doando para uma outra pessoa, mas aí para mim seria como se estivesse dando o meu filho.

Mariana declara sua disposição de doar os embriões para pesquisa, o que explicita que os embriões para ela não são seres humanos em abstrato, mas são dotados de condição humana apenas se forem transferidos e vierem a integrar a rede de parentesco de outros. Os laços de sangue exigem que mãe e filhos fiquem juntos.

Quando se discute a possibilidade de reduzir o número de embriões em casos de gestações múltiplas levantase o questionamento sobre que estatuto deve ser atribuído ao embrião. Débora reagiu com indignação à idéia:

“O que é que é redução? Você escolher quem vai sobreviver, quem não vai? Você vai escolher: tira dois, tira três, tira um... Tira um homem, tira mulher. (...) O que é que é redução? O que você está fazendo com vida? Você está matando? Você está escolhendo quem vai viver, quem não vai? Você tem esse poder? Tem isso, cabe a você falar:

‘Eu quero dois homens e uma menina'; 'Não, eu quero duas meninas e um homem?' “

Débora considera que estariam tirando vidas nesse caso e que esse direito de decidir sobre a vida dos outros não compete às pessoas. Bem mais pragmático, em sua entrevista, o médico do serviço público considerou esse poder de decisão uma necessidade diante das circunstâncias:

“A redução é um aborto, mas é um aborto que você diz: é melhor perder um do que perder cinco. Pelo menos a gente salva dois. A gente vive fazendo isso: escolhendo. O médico escolhe: tem três sujeitos no CTI e chegam mais cinco. Você diz assim, não tem mais vaga, só tem uma vaga, vamos escolher qual é o que pode. Nisso, a gente vive fazendo seleção". 
Marilu vê a perspectiva de redução embrionária de modo mais relacional. Admite que faria em caso de risco de vida para ela e para os filhos, pois pouco adiantaria que todos morressem com ela, que ela perdesse todos, ou que ela morresse e eles sobrevivessem sem mãe.

“Eu acho que ali é uma faca de dois gumes: ou você morre, ou você vai perder os cinco que estão na sua barriga. Você tem opção, o que você não pode é escolher. (...) Eu tiraria, porque eu vou morrer, meus filhos também vão. Por que eu vou viver? Se eu estou vivendo para ter meus filhos. Estou fazendo, fiz um sacrifício para ter meu filho e vou morrer com os cinco aqui. Não vou nem conhecer? Quantos eu tenho que tirar? São dois? Vou fechar o olho e não sei nem quem vai sair, mas tira os dois que eu quero ter pelo menos três. (...) O risco de vida não é para mim, porque, além de morrer, eu ia matar os outros também. Vai morrer os dois, os cinco com você. Eles têm esse risco de vida. Ou então, vão nascer os cinco e você vai morrer. Por quê? Eu não vou nem ver eles? Vou deixar eles no mundo, sem mãe?"

Há duas lógicas regendo as posturas dos informantes quando atribuem a condição humana ao embrião. A primeira é universalista, a segunda é relacional. Na lógica universalista, considera-se o embrião um indivíduo humano em sua essência, dotado dos mesmos direitos que qualquer ser humano nascido, por isso sua vida deve ser preservada independentemente das circunstâncias. O ser humano individual é o valor absoluto e este é visto em isolamento do contexto, daí não ser definido em relação a outro ente. As respostas dos dois médicos, de Edna, de Dalila e, em geral, as de Débora, vão nesse sentido. Na lógica relacional apresentada nos depoimentos de Marilu e Mariana, define-se o embrião em função de outrem. Sua condição se define em relação à sua mãe, parente de sangue, a partir do momento em que se pensa em transferi-lo para o útero e viabilizar seu nascimento e sua inserção em uma rede de parentesco. Marilu diz que doaria seus embriões excedentes para outras pessoas, mesmo sabendo que haveria filho seu com outros, isto é, eles não deixariam de ser filhos dela. Mariana se recusa a doar embriões para outras pessoas, viabilizando o nascimento nas famílias destas, porque seu "sangue fala mais alto". No entanto, Mariana, assim como Marilu, não se oporia a doar seus embriões para a ciência, o que acarretaria eles deixarem de existir como pessoas e parentes e passarem a ser material de pesquisa. Da mesma forma, Marilu permitiria o procedimento de redução embrionária, caso ela e os fetos em gestação corressem risco de vida, pois a morte de todos extinguiria a possibilidade de relação ${ }^{15}$. Em ambas as lógicas, atribui-se a condição de pessoa ao embrião, porém segundo distintos modelos. Os modelos correspondem às representações de parentesco ocidentais, em que se concebe ora a pessoa como ente individual, ora como um ente emaranhado em uma teia de relações sociais (Strathern 1999). 


\section{NATUREZA，TECNOLOGIA E DIVINDADE}

Já se comentou a dimensão da escolha acima no tocante à adoção. A escolha aparece implicada na reprodução assistida de uma forma que o 'parentesco natural' não estaria, o que constrói outras articulações de Natureza e Cultura. A Ciência, em sua versão aplicada que é a tecnologia, permite ampliar as margens de escolha das pessoas que querem ter filhos através de novos métodos. Na instituição que oferece apenas o tratamento convencional para a infertilidade, a médica fala para sua paciente: "Aqui não se faz fertilização in vitro. Vão fazer procedimentos diagnósticos por um ano para ver a causa da infertilidade e tratam. Você e seu marido vão engravidar sozinhos". Enquanto no tratamento convencional o casal engravida "sozinho" (sic), "após os médicos tirarem os obstáculos", na reprodução assistida a mediação da técnica propicia a gravidez, conforme se percebe nas palavras do diretor de um serviço de reprodução humana: "Estamos ajudando um processo que deveria ser natural e não é. Estamos juntando um espermatozóide e um óvulo e rezando para tudo dar certo". Em uma palestra de um serviço de infertilidade, o médico classifica os métodos segundo sua complexidade em: reprodução assistida de baixa tecnologia (inseminação intra-uterina) e de alta tecnologia (fertilização in vitro). A micromanipulação de gametas na ICSI (injeção intra-citoplasmática de espermatozóide) implica um grau de complexidade ainda maior. Mais adiante, na palestra, ele descreve uma técnica para melhorar a qualidade do óvulo em que este recebe parte do citoplasma de um óvulo doado. Embora reconhecendo a eficácia do procedimento, o palestrante qualifica a técnica como "excessivamente sofisticada" (sic). Resta a quem analisa as tecnologias reprodutivas definir o que seria excessivo em tecnologia e porque alguns procedimentos são qualificados dessa forma e outros não. Segundo Strathern (1992), a reprodução era o paradigma de processo natural, mas em função da assistência prestada pelas tecnologias de procriação, ela deixa de ser percebida de tal forma. Esta seria uma das implicações dessas tecnologias. A própria classificação dos métodos em termos de complexidade tecnológica implica um grau maior de intervenção sobre o corpo e um conseqüente afastamento do que é percebido como natural.

$\mathrm{O}$ afastamento dos métodos da natureza também é objeto de reflexão das pacientes. Elizete buscava fazer a cirurgia de reversão de laqueadura quando eu lhe perguntei sobre a opção de fazer a fertilização in vitro. Ela afirmou que preferiria outro jeito, justificando com o receio de troca de material reprodutivo, e completou: "Natural é uma coisa mais segura". A natureza apresentaria menos perigos do que a técnica. Pacientes do Hospital Pérola Byington comentavam na sala de espera sobre a diferença entre fazer o tratamento de inseminação e o de fertilização in vitro: "Inseminação é quase natural, é só uma injeção". Salienta-se que elas mesmas fazem uma classificação das técnicas conforme sua proximidade com o que é considerado natural. Outra paciente do Hospital Pérola Byington, falando da dificuldade de que os embriões se implantem após a transferência, observou: “Bebê 
de proveta é um tipo de gravidez artificial". Por não ser natural, esse início de gravidez é problemático. Betânia comenta sobre a possibilidade de "fazer o bebê de proveta": "No meu pensamento teria que fazer o básico, o normal, como a mulher engravidar do homem". O método parece se afastar do processo natural de reprodução em que a mulher engravida do homem, sem auxílio externo. Os informantes de Costa (2003) também manifestam sua preferência em garantir que o método se aproxime ao máximo do "modelo natural". A reflexão de Marilu, que teve filho por intermédio da reprodução assistida, converge com o pensamento das demais em sua expectativa de engravidar por meio da relação sexual: "A minha vida inteira eu achei que gravidez, a gente tem que transar e engravidar e que aquilo é Deus que botou. Sabe aquela coisa? Eu fiz isso porque eu quis muito e hoje eu não sou contra o processo que eu fiz."

A despeito de frustrar as expectativas de engravidar de forma 'normal', a técnica é vista positivamente porque alcançou resultados. A intervenção humana permite o que seria impossível por causa das condições naturais. Refletindo a partir do conceito de gênero, Taminini (2003) afirma que as novas tecnologias reprodutivas propiciam a reconstrução da natureza em suas falhas, ao remodelar a matéria dos corpos. Parte-se do princípio que o corpo fértil é natural, modificando-se o corpo infértil para capacitá-lo. Em minha pesquisa encontrei o oposto: a ineficiência da fertilidade humana servindo de justificativa no discurso médico para o recurso às técnicas de reprodução assistida (Luna 2004). Mariana fala de forma positiva do tratamento:

"Aí começou todo esse processo de medicamento, de vacina, de injeção de hormônio que você faz para produção de óvulos, todo esse processo. Foi tudo muito mais fácil e rápido do que eu imaginava. (...) E como o homem pode intervir na natureza da coisa. Entendeu? Pode entrar e fazer. (...) Graças a Deus, eu tive acesso a isso. Que loucura você pensar que a ciência chegou a mim".

Nem sempre a intervenção humana na natureza é vista positivamente, como se depreende pela opinião de Mariana sobre a clonagem humana: "Ah, isso é uma viagem total. Não existe. Não tem que acontecer. Isso é sair demais da coisa da natureza, entendeu? Não aceito. Não concordo".

Se a clonagem sai demais da natureza, é porque a natureza estabelece alguns parâmetros a serem seguidos. Hirsch (1999) identificou esse tipo de tensão quanto às novas tecnologias reprodutivas em sua pesquisa de campo: é aceitável que tais técnicas aperfeiçoem a natureza, desde que permanecendo fiéis aos princípios da natureza. A postura de Marilu quanto à clonagem humana é semelhante:

“Isso aí já está passando dos limites, entendeu? Vai virar máquina. Daqui a pouco não vai virar mais humano, vai virar máquina. Aperta um botão e sai um menininho ali para você daí a pouco, entendeu? Quer louro de olho azul? Aperta um botão. Não precisa nem ficar nove meses na barriga. Isso aí já é... Pode ser que mais tarde isso seja normal, mas hoje eu já sou... acho nada a ver. Acho que não tem Deus aí não. Acho que não tem natureza. $E$ a natureza, a gente vai abrir mão da natureza, né? Abrir mão demais da natureza que é uma coisa tão linda que a gente tem". 
O excesso seria o ser humano virar máquina e se reproduzir como máquina. Esse tipo de reprodução não natural permitiria a escolha de todos os aspectos do filho tal qual um produto, além de prescindir da gravidez. Salienta-se a associação de ausência de Deus e de ausência de natureza no projeto da clonagem humana.

A intervenção humana através da razão resulta da vontade divina para Marilu: “Como eu falei para você, Deus não queria que eu fosse mãe, eu achava isso. Um dia eu pensei: 'Não. Deus deu ao homem inteligência de fazer isso. As mulheres serem mães, quem não podia, quem não pode' “.

É recorrente no depoimento das informantes invocar a vontade de Deus para explicar situações de esterilidade. Mereceria um tratamento estatístico à parte o número das mulheres que formularam opiniões ou repetiram expressões ditas por seus maridos ou familiares do tipo: "Deus sabe o momento certo de vir o filho", "é da vontade de Deus", "quando Deus quiser virá", além de conselhos para "ter fé em Deus" ou "esperar em Deus". Moema diz: "Se eu tiver de ter, eu vou ter. Se não tiver, Deus sabe das coisas". Não apenas as pacientes faziam esse tipo de observação, também profissionais evocavam a vontade divina. Uma médica dizia: "A gente não engravida ninguém, quem engravida é Deus". Para outra paciente ansiosa ela falou: “Quem decide quando ter filho é Deus e a pessoa não pode se cobrar isso... Os médicos tiram apenas as pedras do caminho". A mãe da paciente reagiu: "Abaixo de Deus está o médico. A gente precisa confiar no médico e esperar que ele dê informações". A menção a Deus nesses diálogos não é casual, pois fertilidade e infertilidade são consideradas bênção ou castigo divino nas representações de maternidade de classes populares (Dauster 1983). Segundo Dauster, o tema do filho como dádiva de Deus tem por pressuposto a reprodução humana como uma evidência da relação entre as instâncias divina e humana. A experiência de Andressa exemplifica isso. Ela perdeu as trompas e não pôde mais engravidar. Algumas pessoas falavam que isso era "coisa de Deus", mas, estudando a Bíblia, Andressa aprendeu que "Deus criou homem e mulher para ter filhos". Ela viu então que "tinha direito a ter filhos" e decidiu-se a buscar o tratamento de fertilização in vitro. Andressa, da mesma forma que Marilu (acima), vê na técnica um instrumento humano para efetivar as bênçãos de Deus na procriação. Há um paralelo aqui entre Deus e Natureza, com a técnica gerada pelo desenvolvimento cultural humano intervindo na Natureza para dar assistência ao processo reprodutivo. Não foi por acaso que na observação de Marilu a clonagem humana estava em oposição a Deus e à Natureza. Os parâmetros da Natureza foram estabelecidos por Deus e devem ser respeitados para garantir a perpetuação da espécie humana mesmo com a intervenção da técnica. A dimensão da transcendência está presente no processo reprodutivo. Na reprodução, articulam-se "três eixos: o do sagrado, o da natureza e o da cultura" (Dauster 1983:21). 
Neste artigo, apresentaram-se as convergências temáticas no tocante às representações de pessoa e de parentesco de grupos heterogêneos de informantes. A despeito dessa heterogeneidade, há pelo menos uma grande categoria presente para todos: o sangue. A preocupação com o uso das técnicas é propiciar o parentesco de sangue. Sangue às vezes se aproxima do discurso biomédico e vira DNA. Mas a preocupação com o sangue ultrapassa questões de medicalização da herança genética. O sangue garante a semelhança física e de caráter entre pais e filhos. Se o DNA foi evocado como nexo entre as pessoas, a gravidez, mesmo na ausência dos genes certos em caso de doação de gametas, é outra forma de criar vínculos de substância entre mãe e filhos, transmitindo alimento, amor e traços da personalidade. As tecnologias de procriação permitem a circulação de substâncias germinativas entre as pessoas sem o ato sexual, criando situações novas interpretadas em termos antigos: incesto, adultério, adoção. Algumas vezes os sujeitos das técnicas são células, novas figuras de parentesco emergentes. Há uma preocupação com o sangue na geração imediata, já as genealogias são deixadas de lado.

Natureza, Deus e Ciência se conjugam para permitir a reprodução: ter filhos é processo natural; é dádiva de Deus; são os médicos que fazem engravidar. Embora reconhecendo o caráter artificial das técnicas em contraste com o ato sexual e a reprodução, vistos como naturais, o discurso das informantes manifesta pouco interesse em opor o que é cultural e o que é natural no parentesco. Verifica-se que relações podem ser ocultadas como irrelevantes para o parentesco ou destacadas como constitutivas deste, alternando-se parâmetros biológicos e sociais. Às vezes surge a oposição entre sangue e criação/educação. Porém, o que importa de fato é considerar verdadeiro o vínculo de pertencimento e proteger o vínculo da instabilidade, independentemente se esta vem de fatores legais ou de técnicas reprodutivas. A herança de sangue mescla o natural e o social. A gravidez é descrita como a atividade social de cuidar dos filhos, os significados se permutando entre o natural e o cultural. A Ciência, resultado da invenção humana e pertencente à esfera da Cultura, pode auxiliar a Natureza, desde que não contrarie seus princípios gerais.

Identificou-se um sistema comum de símbolos e representações de parentesco em que as pessoas são definidas relacionalmente a partir de seus laços de sangue, sangue este percebido como uma herança que envolve tanto o lado biogenético como a tradição de família. Essa noção difere de uma visão biologizante de hereditariedade apresentada por certos segmentos da área de biomedicina, em que o comportamento social está inscrito nos genes. Pode haver uma origem comum, e mesmo comunicação com intercâmbio de significantes como o teste de DNA entre essas duas visões de 'herança', mas uma não se reduz à outra. 
Por fim, há mais do que mera alternância de parâmetros biológicos e sociais para fundamentar as relações de parentesco e a representação de pessoa, como se percebe pela categoria de sangue, que compreende aspectos biológicos e sociais, ao articular Natureza e Cultura. A análise das novas tecnologias reprodutivas permite vislumbrar como Natureza e Cultura não são domínios estanques, mas que há um fluxo contínuo de significados, um intercâmbio em que significados naturais são culturalizados e significados culturais são naturalizados. A Natureza ora serve de modelo à Cultura, ora o entendimento pela Cultura se impõe à Natureza. 


\section{NOTAS}

1 Baseado em comunicação de mesmo título apresentada no GT "Pessoa e Corpo: Novas Tecnologias Biológicas e Novas Configurações Ideológicas", coordenado por Luiz Fernando Dias Duarte e Jane Russo durante o XXVI Encontro Anual da ANPOCS, em 2002.

2 Os resultados completos da pesquisa estão em Luna (2004).

3 Todos os nomes de informantes foram alterados para manter sua privacidade. Os nomes fictícios das quatro entrevistadas que já passaram por tratamento de reprodução assistida são Edna, Débora, Mariana e Marilu. As demais informantes nomeadas procedem do Instituto de Ginecologia da UFRJ.

4 Finkler (2001), pesquisando no contexto muito mais medicalizado dos EUA, fala da representação de que os testes de DNA revelam a verdade, por isso as pessoas não podem inventar ascendentes.

5 Na novela de Glória Perez, a personagem Deusa procura o método de fertilização in vitro no intuito de conseguir um doador parecido com o seu companheiro que era estéril. O cientista, Dr. Albieri, utiliza seus óvulos para uma experiência de clonagem. Sem saber, ela recebe um embrião que é o clone de outro personagem. Na clonagem por transferência nuclear, o óvulo enucleado recebe o núcleo de uma célula adulta e porta a carga genética do fornecedor da célula, exceto pelo DNA das mitocôndrias da fornecedora do óvulo que permanecem no citoplasma (Luna 2003).

6 O depoimento de meus informantes contrasta com os dos casais usuários da reprodução assistida entrevistados por Tamanini (2003) que identificam mãe com quem "gera" (a gestante) e consideram o óvulo apenas uma ajuda. A maioria de minhas informantes rejeitava a doação de óvulos tanto com base no desejo do vínculo genético, como por temer conflitos com a doadora. Todavia a rejeição ao recurso da cessão temporária de útero (barriga de aluguel) foi maior do que à doação de óvulos.

7 Refere-se a Barriga de Aluguel, novela de Gloria Perez em que Ana, uma mulher com problemas no útero, contrata Clara para ser mãe gestacional substituta, recebendo o óvulo de Ana fecundado com o esperma do marido desta. Após o nascimento, Clara se recusa a entregar o bebê e ocorre uma disputa pela tutela da criança.

8 Ainda não há técnica eficaz de congelamento de óvulos como existe para sêmen. Isso exige que doadora e receptora freqüentem na mesma época o serviço de reprodução assistida.

9 Embora sem precisão estatística, em minha observação etnográfica constatei que entre as mulheres oriundas das camadas mais desfavorecidas das classes populares o elogio à dor do parto esteve mais presente, sendo um rito de passagem necessário. Tais afirmações desconcertavam médicos menos experientes, oriundos das camadas médias, que as atendiam.

10 Faz-se um acordo em que a receptora pagará o tratamento da doadora. Como há poucas mulheres dispostas a doar seus óvulos, algumas clínicas promovem essa troca para atrair doadoras interessadas em ter filhos por fertilização in vitro, mas que não poderiam arcar com as despesas do tratamento, na chamada doação compartilhada (Cf. Luna 2004).

11 O que fica sugerido nessa exclusão é a inexistência de clientela negra ou com ascendentes próximos negros nas clínicas particulares de reprodução assistida.

12 Costa (2003) encontrou resistência a aceitar a doação de sêmen entre seus informantes em tratamento de infertilidade ou em busca de planejamento familiar.

13 Inspirei-me na observação de Franklin (1998) de que, no contexto do debate legislativo sobre a reprodução assistida na Inglaterra, características pessoais, sociais e relacionais eram atribuídas a micro-entidades definidas pela biologia tais como óvulos, espermatozóides, zigotos.

14 Franklin (1998) descreve a representação do embrião como um ancestral comum a todos, um fato universal de humanidade compartilhada, uma vez que todos os seres humanos já foram embriões.

15 A lógica universalista estaria relacionada à ideologia individualista moderna, enquanto a lógica relacional, invocando o sangue como vínculo, teria continuidade com ideologias holistas (Dumont 1997). 


\section{REFERÊNCIAS BIBLIOGRÁFICAS}

ABREU FILHO, Ovídio de. 1982. "Parentesco e Identidade Social". Anuário Antropológico/80: 95-118.

CONSELHO FEDERAL DE MEDICINA. Resolução n 1358/92, de 11 de novembro de 1992. Dispõe sobre normas éticas para a utilização das técnicas de reprodução assistida. In Eduardo Oliveira Leite (1995) Procriações Artificiais e o Direito: Aspectos Médicos, Religiosos, Psicológicos, Éticos e Jurídicos. São Paulo: Editora Revista dos Tribunais.

COSTA, Maria Cecília Solheid. 1988. Os 'Filhos do Coração': adoção em camadas médias brasileiras. Tese de doutorado. Rio de Janeiro: PPGAS/ Museu Nacional, UFRJ.

COSTA, Rosely. 2003. “Tecnologias Reprodutivas e Atribuições de Paternidade e Maternidade". In: M. Grossi, R. Porto \& M. Tamanini (orgs.) Novas Tecnologias Reprodutivas Conceptivas: questões e desafios. Brasília: LetrasLivres.

CUSSINS, Charis M. 1998. “Quit Sniveling, Cryo-baby. We'll work out which one's your mama”. In R. Davies-Floyd \& J. Dumit (eds.) Cyborg Babies: from techno-sex to techno-tots. New York: Routledge.

DAUSTER, Tania. 1983. “O Lugar da Mãe". Comunicações do ISER 2(7): 20-26.

DUMONT, Louis. 1997. Homo hierarchicus: o sistema de castas e suas implicações. 2.ed. São Paulo: Edusp.

EDWARDS, Jeanette. 1999 [1993]. “Explicit Connections: ethnographic enquiry in northwest England. In J. Edwards et al. Technologies of Procreation: kinship in the age of assisted conception. 2. ed. London \& New York: Routledge.

FINKLER, Kaja. 2001. "The Kin in the Gene: the medicalization of family and kinship in American society". Current Anthropology 42(2): 235-63, Abr.

FONSECA, Claudia. 1995. Caminhos da Adoção. São Paulo: Cortez.

. 2002. "A vingança de Capitu: DNA, escolha e destino na família brasileira contemporânea". In C. Bruschini \& S. G. Unbehaum (orgs.) Gênero, Democracia e Sociedade Brasileira. São Paulo: Fundação Carlos Chagas/ Edições 34.

. 2003. "Paternidade e DNA: a certeza que pariu a dúvida". II Seminário Internacional; I Seminário Norte-Nordeste Homens, Sexualidade e Reprodução: Tempos, Práticas e Vozes. Comunicação apresentada na mesa redonda "Sexualidade, Masculinidade e Reprodução". Recife, 17 a 20 de junho.

FRANKLIN, Sarah. 1999. "Making Representations: the parliamentary debate on the Human Fertilisation and Embryology Act". In J. Edwards et al. Technologies of Procreation: kinship in the age of assisted conception. 2. ed. London \& New York: Routledge.

HÉRITIER, Françoise. 1994. Les Deux Soeurs et leur Mère: anthropologie de l'inceste. Paris: Éditions Odile Jacob.

HIRSCH, Eric. 1999 [1993]. “Negotiated Limits: interviews in south-east England”. In J. Edwards et al. Technologies of Procreation: kinship in the age of assisted conception. 2. ed. London \& New York: Routledge.

LAQUEUR, Thomas. 1992. Making Sex: Body and Gender from the Greeks to Freud. Cambridge \& London: Harvard University Press.

LUNA, Naara. 2002. "As Novas Tecnologias Reprodutivas e o Estatuto do Embrião: um discurso do magistério da lgreja Católica sobre a natureza". Revista Gênero 3(1): 83-100. 
2003. "Novela e Biotecnologia: os pais de 'O Clone' segundo mulheres em tratamento de infertilidade". In : M. Grossi, R. Porto \& M. Tamanini (orgs.) Novas Tecnologias Reprodutivas Conceptivas: questões e desafios. Brasília: LetrasLivres.

2004. Provetas e Clones: Teorias da Concepção, Pessoa e Parentesco nas Novas Tecnologias Reprodutivas. Tese de Doutorado. Rio de Janeiro: Programa de Pós-Graduação em Antropologia Social, Museu Nacional/ UFRJ.

MARTIN, Emily. 1991. “The Egg and the Sperm: how science has constructed a romance based on stereotypical malefemale roles". Signs 16(3): 485-501.

PISCITELLI, Adriana. 1998. “Nas Fronteiras do Natural: gênero e parentesco". Revista Estudos Feministas 6(2): 305321.

SALEM, Tania. 1995. “O Princípio do Anonimato na Inseminação Artificial com Doador (IAD). Physis - Revista de Saúde Coletiva 5(1):33-68.

SCHNEIDER, David. 1968. American Kinship: a cultural account. New Jersey: Prentice-Hall.

STRATHERN, Marilyn. 1992. Reproducing the Future: essays on anthropology, kinship and the new reproductive technologies. Manchester: Manchester University Press.

1999 [1993]. "Regulation, Substitution and Possibility." In J. Edwards et al. Technologies of Procreation: kinship in the age of assisted conception. 2. ed. London \& New York: Routledge.

TAMANINI, Marlene. 2003. “Deslocamentos de Gênero: a ordem tecnológica de ajuda a natureza nas relações do paternar e do maternar". V Reunião de Antropologia do Mercosul. Florianópolis, 30 de novembro a 3 de dezembro de 2003. Disponível em: www.antropologia.com.br/tribo/vram/ e www.antropologia.com.br/arti/colab/vram2003-mtamanini.pdf. Acesso em: 24/04/2005.

WAGNER, Roy. 1981. The Invention of Culture (revised and expanded edition). Chicago \& Londres: The University of Chicago Press. 


\section{Novas Tecnologias Reprodutivas: Natureza e Cultura em redefinição}

\section{RESUMO}

As novas tecnologias reprodutivas, procedimentos médicos que substituem o ato sexual para a concepção, são objeto privilegiado na Antropologia para se debater a relação entre Natureza e Cultura. Schneider lança a hipótese que, sendo a conexão biogenética a definição fundante da concepção norteamericana de parentesco, a descoberta pela ciência de novos fatos sobre a relação biogenética transformaria noções nativas ocidentais. A assistência dessas tecnologias questiona não somente a naturalidade do processo reprodutivo, ao ampliar as margens de escolha na reprodução e na constituição do parentesco, mas afeta a noção de natureza como condições de vida isentas de intervenção. Baseado em observação etnográfica e entrevistas, o artigo analisa o discurso de profissionais e pacientes envolvidos com a reprodução assistida e tratamentos convencionais de infertilidade. O foco está em como concepções de pessoa e parentesco formuladas sobre vivências e práticas concernentes às tecnologias reprodutivas se referem às categorias de Natureza e Cultura.

PALAVRAS CHAVE: novas tecnologias reprodutivas, Natureza, Cultura, parentesco, pessoa.

\section{New Reproductive Technologies: redefining Nature and Culture}

\section{ABSTRACT:}

Anthropology has discussed Nature/Culture opposition through the analysis of the new reproductive technologies, medical procedures aiming at conception which replace sexual intercourse. According to Schneider's hypothesis, Western notions of kinship will change if Science discovers new facts regarding biogenetic relationships, which is the basis of American kinship conception. Technologies' assistance questions not only the natural aspect of the reproductive process, by broadening the margin of choice in the reproduction and constitution of kin, but also compromises the definition of nature as conditions of life from which intervention is absent. The article is based on ethnographic observation and interviews with professionals and patients dealing with assisted reproduction and conventional infertility treatment, and analyses their discourse. The text focuses on how notions of personhood and kinship related to the new reproductive technologies refer to the concepts of Nature and Culture. KEY WORDS: new reproductive technologies, Nature, Culture, kinship, personhood. 